\title{
Gonadotrophin-induced changes in the Sertoli cells of the immature mouse testis
}

\author{
A. G. Davies \\ Department of Physiology, Medical School, University of Birmingham, \\ Birmingham B15 2TJ, U.K.
}

\begin{abstract}
Summary. Highly purified preparations of human pituitary gonadotrophins were administered to immature male mice daily for 3 days. The mice were killed on the 9 th day after birth and the testes were prepared for electron microscopy. FSH treatment caused an increase in the mass of Sertoli cell cytoplasm, and FSH and LH increased the size of mitochondria in these cells. The number of polysomes in each Sertoli cell was increased after FSH treatment, but the number of ribosomes/polysome was not affected.
\end{abstract}

In a previous study the number of Sertoli cells in the immature mouse was increased after treatment with a relatively crude preparation of FSH (Davies, 1971). The amount of cytoplasm/Sertoli cell also appeared to increase but could not be confirmed with the light microscope because it was not possible to see the plasma membranes of the testicular cells clearly. The effect of FSH on the Sertoli cell cytoplasm has therefore been reinvestigated with the electron microscope, and highly purified gonadotrophin preparations have been used.

The FSH was prepared by the method of Butt, Crooke \& Cunningham (1961) and had a potency of $2000 \mathrm{i} . \mathrm{u} . / \mathrm{mg}$ with an $\mathrm{LH}$ activity of $88 \mathrm{i} . \mathrm{u} . / \mathrm{mg}$. The LH, prepared by the method of Stockell Hartree (1966), had a potency of 5300 i.u./mg and an FSH activity of $<10$ i.u./mg. Four groups of 4CFW mice were fostered by pairs of lactating females. One mouse in each group received daily s.c. injections of $0.9 \% \mathrm{NaCl}, 5$ i.u. FSH, 20 i.u. LH, or 5 i.u. FSH +20 i.u. LH on the 6th, 7 th and 8 th day after birth. The animals were killed on the 9 th day and four fragments of testis from each mouse were fixed in glutaraldehyde, post-fixed in osmium tetroxide and embedded in Epon. Three thin sections were cut from each fragment and stained with lead citrate. The sections were viewed at a magnification of $\times 10,000$ and the type of histological structure (Sertoli cell cytoplasm, Sertoli cell nucleus, germinal cell cytoplasm, germinal cell nucleus, tubular basement membrane and tunica propria, and interstitial tissue including vessels) at 1200 randomly-distributed points in one testis from each mouse was recorded. An estimate of the total mass of each type of histological structure was obtained by multiplying the weight of the testes minus tunicae (see Davies, 1971) by the proportion of randomly-distributed points overlying that type of structure. Micrographs giving magnifications of $\times 4500$ and $\times 21000$, were used for making counts of Sertoli cell mitochondria and polysomes, for counting the number of ribosomes per section of polysome, and for measuring the area of profiles of mitochondria by planimetry. In each of eight mice comprising two foster groups the area of 40 Sertoli cell nuclei was also measured. Results were evaluated statistically by analyses of variance.

The mean weight per pair of testes was $12.3 \mathrm{mg}$ in the mice which had received FSH and $9.1 \mathrm{mg}$ in those which had not $(P<0.001)$. There was aiso a significant increase in the weight of the testes minus the tunicae albugineae. Neither weight was affected significantly by LH treatment. FSH treatment increased the total mass of Sertoli cell cytoplasm by $62 \%$ and also caused significant increases in the total masses of Sertoli cell nuclei, germinal cell cytoplasm and interstitial tissue (Table 1). In mice which had received FSH there was a significantly larger ratio of cytoplasm to nucleus in the Sertoli cells (mean increase of $28 \%, P<0.001$ ) but not in the germinal cells. Since there was no apparent change in the size of the Sertoli cell nuclei, the ratio change represents an increase in the amount of cytoplasm per Sertoli cell. The only significant effect of $\mathrm{LH}$ on tissue element mass was augmentation of the action of FSH on the total amount of Sertoli cell cytoplasm $(P<0.01$ for hormone interaction). 
Table 1. The mean mass ( $\mathrm{mg} /$ pair of testes) of each tissue type studied in the testes of immature mice after gonadotrophin treatment

\begin{tabular}{|c|c|c|c|c|c|c|}
\hline \multirow[b]{2}{*}{ Treatment } & \multicolumn{2}{|c|}{ Sertoli cell } & \multicolumn{2}{|c|}{ Germinal cell } & \multirow{2}{*}{$\begin{array}{l}\text { Tunica } \\
\text { propria }\end{array}$} & \multirow{2}{*}{$\begin{array}{c}\text { Interstitial } \\
\text { tissue }\end{array}$} \\
\hline & Nucleus & Cytoplasm & Nucleus & Cytoplasm & & \\
\hline Saline & 1.45 & $3 \cdot 15$ & 0.86 & 1.04 & 0.52 & $1 \cdot 01$ \\
\hline FSH & $1 \cdot 74$ & $4 \cdot 38$ & 0.94 & $1 \cdot 24$ & 0.47 & $1 \cdot 39$ \\
\hline $\mathbf{L H}$ & $1 \cdot 46$ & 3.03 & 0.75 & $1 \cdot 02$ & 0.53 & $1 \cdot 08$ \\
\hline $\mathrm{FSH}+\mathbf{L H}$ & 1.97 & $5 \cdot 63$ & 0.94 & $1 \cdot 27$ & 0.63 & $1 \cdot 38$ \\
\hline \multicolumn{7}{|l|}{ Significance for } \\
\hline FSH effect & $P<0.01$ & $P<0.001$ & $P>0 \cdot 1$ & $P<0.05$ & $P>0.1$ & $P<0.01$ \\
\hline
\end{tabular}

The mean area $\left(\mu \mathrm{m}^{2}\right)$ of profiles of Sertoli cell mitochondria was increased by FSH and by LH (0.370 and 0.363 respectively compared with 0.285 for controls; $P<0.025$ for each hormone). When both hormones were given their effects were additive $(0 \cdot 445)$. FSH treatment decreased the number of mitochondrial profiles $/ 100 \mu^{2}$ ( 29.5 for FSH alone, 33.5 for $\mathrm{LH}$ and 29.8 for FSH $+\mathrm{LH}$ compared with 35.5 for controls; $P<0.025)$ but had little effect on the number/cell because the amount of cytoplasm was increased. The number of mitochondria/unit volume could not be calculated because the thickness of the sections was not measured. The number of polysomes/unit area of section was not altered by gonadotrophin treatment, but because FSH increased the amount of cytoplasm the number of ribosomes/Sertoli cell was increased. The number of ribosomes/polysome was not affected by FSH or LH treatment.

Murphy (1965) found that injections of FSH into the testes of hypophysectomized immature mice not only increased the amount of cytoplasm but also caused vacuolation of the Sertoli cells and damaged the germinal cells. These deleterious effects did not occur in the present experiment.

The dependence of immature interstitial tissue on FSH but not LH is in accord with biochemical evidence. Administration of FSH to mice from the 6th to the 9th day after birth increases the activity of the interstitial cell enzyme, glucose-6-phosphate dehydrogenase (Hitzman, 1971), and FSH treatment enhances the subsequent ability of the immature rat testis to secrete testosterone in response to stimulation by LH (Odell \& Swerdloff, 1973).

The enlargement of the Sertoli cell mitochondria in mice treated with FSH and with LH may have been associated with an increased respiratory rate in these cells because Steinberger \& Wagner (1961) showed that gonadotrophins stimulate respiration in adult rat testes which have been depleted of germ cells. As in the present study with mice, gonadotrophin treatment has been shown to increase the total number of ribosomes in the rat testis but does not affect the proportion of ribosomes aggregated into polysomes or the relative numbers of polysomes of different sizes (Abney, Skipper \& Williams, 1974; Means, 1974).

The results reported in this paper suggest that the development of the Sertoli cells is dependent upon FSH. The incorporation of tritiated lysine into protein in vivo is stimulated in the testes of neonatal mice by FSH (Davies, Davies \& Sumner, 1975). It is likely that the greater part of the newly synthesized protein is structural protein in the Sertoli cells, which form $75 \%$ of the intratubular cells in mice of this age (Davies, 1971).

I thank Dr Butt and Dr Stockell Hartree for supplying the preparations of gonadotrophin and M. Courtens of the Centre de Recherches de Tours for preparing the EM sections. Part of this work was performed during tenure of an Anglo-French Medical Research Scholarship.

\section{References}

Abney, T.O., Skipper, J.K. \& Williams, W.L. (1974) Gonadotrophin stimulation of rat testicular protein synthesis. Polysome isolation and activity in a cellfree system. Biochemistry, N.Y. 13, 3956-3962. 
Butt, W.R., Crooke, A.C. \& Cunningham, F.J. (1961) Studies on human urinary and pituitary gonadotrophins. Biochem.J.81, 596-605.

DAvies, A.G. (1971) Histological changes in the seminiferous tubules of immature mice following administration of gonadotrophins. J. Reprod. Fert. 25, 21-28.

Davies, A.G., Davies, W.E. \& Sumner, C. (1975) Stimulation of protein synthesis in vivo in immature mouse testis by FSH. J. Reprod. Fert. 42, 415-422.

Hitzman, J.W. (1971) Effects of gonadotrophins and testosterone on the testes of prepubertal mice. $J$. exp. Zool. 178, 369-376.

Mrans, A.R. (1974) Minireview: early sequence of biochemical events in the action of follicle-stimu- lating hormone on the testis. Life Sci. 15, 371-389.

MURPHY, H.D. (1965) Sertoli cell stimulation following intratesticular injections of FSH in the hypophysectomized rat. Proc. Soc. exp. Biol. Med. 118, 1202-1205.

ODELL, W.D. \& SWERdLofF, R.S. (1973) FSH modulation of sensitivity to LH-stimulation of testosterone secretion: role in sexual maturation. In Program 55th A. Meeting, Endocr. Soc. A-94, Oklahoma City.

STEINBERGER, E. \& WAGNER, C. (1961) Observations on the endogenous respiration of rat testicular tissue. Endocrinology 69, 305-311.

Stockell Hartree, A. (1961) Separation and partial purification of the protein hormones from human pituitary glands. Biochem. J. 100, 754-761.

Received 25 July 1975 